The Social Sciences 6 (2): 81-86, 2011

ISSN: $1818-5800$

(C) Medwell Journals, 2011

\title{
The Outsider Within: The Expatriate Writer in Malaysia
}

\author{
Jamaluddin Aziz and M.M. Raihanah \\ School of Media and Communication Studies, \\ Faculty of Social Sciences and Humanities, \\ University Kebangsaan of Malaysia, 43600 Bangi, Selangor, Malaysia
}

\begin{abstract}
Pennsylvania-born Robert Raymer moved to Malaysia $>25$ years ago (1985) and since then has written several stories by using Malaysia, especially Penang as the major setting. The proximity through matrimony that is claimed by the author in the introduction of the anthology on the surface ideally provides him a closer perspective of the society as the access through marriage entails openness to the details and nuances of the culture and people of the land. However, using narratology as an approach, this study problematises Raymer's claim and argues that instead of revealing the Malaysian society as an insider, the narrator and narration ironically expose the author's point of view as an outsider. Indeed, the narratological space constructed in this anthology is self-conscious, illusory and ironic. Instead of creating spatial proximity, the narratological space functions as a conduit for imposing the author's masculine American gaze on the vision of what he thinks constitutes Malaysia or Malaysians, especially as epitomized by the female characters. It is within the American expatriate position and his mythos that the journey West symbolizes the promised frontier of hopes and dreams. Raymer's journey East, however is filled with nightmares and xenophobia thus, undermining the validity of his claim of a connected through marriage insider.
\end{abstract}

Key words: Emasculated narrator, American dream, expatriate writer, narratology, spatial proximity, Malaysia

\section{INTRODUCTION}

My original goal in writing this story (neighbors) and others in Lovers and Strangers Revisited was to depict Malaysia not from the viewpoint of an outsider, an expat generalizing from a distance but as a connected through marriage insider (Raymer, 2005). Pennsylvania-born Robert Raymer moved to Malaysia $>25$ years ago (1985) and since then has written several stories by using Malaysia, especially Penang as the major setting. Married to Malaysians, his ex-wife was a Malay and his present is a Sarawakian from East Malaysia, Raymer has very impressive and psychedelic credentials under his belt which resonate ostensibly well with some of the stories and people he has written about.

Bhatt for instance opines that with his keen observations and personal interactions, Raymer went on to write a collection of short stories featuring myriad Malaysian characters. As Raymer (2006) states in the excerpt above, his writings specifically, the collection of short stories titled Lovers and Strangers Revisited is rooted in his positionality as the insider of the Malaysian society, albeit through marriage. The proximity through matrimony as claimed by the author in the introduction of the anthology at the surface level, ideally provides him a closer and more intimate entrée into the society. It in effect, allows access to the details and nuances of the culture and people of the land. However, using narratology as an approach this study problematises Raymer's claim and argues that instead of revealing the Malaysian society as an insider, the narrator and narration ironically expose the author's point of view as an outsider.

Lovers and Strangers Revisited consists of 15 short stories previously published in 9 countries including London Magazine in United Kingdom and Northern Perspective in Australia and some have undergone numerous revisioning.

All of the stories deal with different issues in life however, the apparent leitmotif of the power struggle between lovers and strangers works as a palimpsest for something else and that something else is Raymer's penchant for self-creation, a typical characteristic of an American pursuing his American dreams as the raison detre of American dream is self-creation and the journey West (Aziz, 2008; Lee, 1965).

Corresponding Author: Jamaluddin Aziz, School of Media and Communication Studies, Faculty of Social Sciences and Humanities, University Kebangsaan of Malaysia, 43600 Bangi, Selangor, Malaysia 
The leitmotifs of romantic disillusionment and forlornness run deep in many of the stories in the collection making this an interestingly dark and bizarrely readable collection. Stories like the satirical neighbors, the mystical smooth stones, the comically dark sisters room and to a certain extent, the narcissistic Mat Salleh, offer a disturbingly honest depiction of humans obsession with monetary/material belongings. This obsession essentially evokes the existential loneliness and alienation of the narrator which are not lost in the revisioning process. Arguably, the protean and disparate stories united by two common themes above which are the strong points of the book, represent Raymer's versatility as a short story writer. His prose is generally simple and direct, giving an almost Orwellian feel to it.

For that reason, the primary interest in this study is to examine the underlying ideological motifs of Raymer's work, paying particular attention to how its narratological space his position as a connected through marriage insider that he creates between him, his narrators, the characters and to a certain extent the reader helps to illuminate its leitmotif of romantic forlornness and disillusionment. This study also contests Raymer's construction of Malaysia and her people and suggests that the authors standpoint is rooted not in the proximity but in the distance/detachment he creates as an American expatriate.

\section{ROMANTIC FORLORNNESS AND THE EMASCULATED NARRATOR}

The leitmotif of romantic forlornness is often directly linked to the narrators emasculation. In the last two stories in the book, Dark Blue Thread and Miss Valerie, the narrators virility is constantly challenged by independent local women. In Dark Blue Thread, the narrator, an American is married to a Malaysian, Salina and moves to Malaysia. His wife is the sole breadwinner while he is a struggling writer, relying on the former to provide him with pocket money.

At one point of the story, the narrator admits to feeling like a trophy husband used to impress and this emasculation consequently results in him feeling suicidal: the same knife he had considered slashing his wrists 2 weeks ago. The narrator appears to draw the readers into the narratological space at this juncture, towards developing a sense of sympathy for the expatriates state of affairs. Indeed, through the pitiful American character, the reader is made aware of and even complicit in the emasculation that he undergoes at the hand of the femme fatale wife. This is achieved by imbuing the dangerous woman with excessive femininity (Salina slipped on her black heels) and phallic association (grabbed an umbrella to ward off the sun) hence, creating a clash of images. This clash in turns creates for the narrator, a fragmented and destabilized female subject hence, her dangerous sexuality and duende.

The same narrative technique is used in Miss Valerie to evoke similar thematic concern. This story is set in Singapore where the female character, Valerie, a pan-Asian married woman from Penang, meets up with Jason Glasgow, an American writer. Glasgow is astonished by the uncanny physical resemblance between Valerie and Rebecca, the lady whom he had an affair with and who later committed suicide which according to the narrator was triggered by his suggestion. However, unlike Dark Blue Thread, the eponymous female character is not only the femme fatale but she is also associated with madness. In psychoanalytic sense, the notion of madness always refers to the dichotomy of male equals normal/female equals abnormal schism.

Indeed, Raymer constructs the character of Rebecca as a femme fatale, a woman who even in her death, speaks trouble and fatality. Valerie is then constructed as Rebeccas double, possessing a different kind of fatality that Rebecca had. Instead of consigning Valerie to the role of a bona fide femme fatale, she is made a redeeming figure a sign that Raymer is clever in the construction of this narrative doubling or doppelganger.

The expatriate narrator has to resort to this kind of narrative strategy as a way of reclaiming his masculinity which he regains upon the suicide of Valerie a parallelism of Rebeccas tragic death and the news that she had his baby before her suicide, his life finally seemed more complete. The two female characters death is then seen as ideologically driven hence, very necessary for the narrator to claim his masculinity.

The emasculated narrator in this anthology is also positioned as an emotionally detached observer who epitomizes a strangers romantic forlornness. This is especially remarkably true in the second story in the collection, The Future Barrister. In this story, Raymer appears to position his western narrator strategically in narratological sense to avoid any association between him and the main characters. Yet, the narrative technique has backfired. Through, the male Malaysian Indian character of whom the narrator conveniently named Clark Gable, the story gradually unravels the narrators longing for romantic and human contacts.

The subconscious use of a doppelganger narrative creates a parallelism that allows the Indian lad to be the physical or literal manifestation of the narrators own 
romantic disillusionment that is not only the longing for his ex-wife but also the acceptance by local people.

Perhaps, the Malaysian Indian character is the narrators evil reincarnated, wishing he should have done to his wife what Clark Gable had done to Sara, i.e., murdering her. This narrative technique, moreover is the key to the understanding of the characters psyche both characters drink to fill up the emptiness in them: it was empty and so was mine.

There is something fundamentally existential here which harks back to the narrators romantic forlornness, his wanting to find meaning in humanity amidst peoples desire for money and sex. The story ends in a splenetic tone, revealing the standard American romance which is described by Leslie Fiedler as a masculine individualism, living by its wits and avoiding social, economic and sexual entanglements (Naremore, 1998).

Teh-0 in KL which is the 9rh story in the collection, picks up this narrative doubling and the theme of American romance. This time, Raymer is more blatant in his attempt to reinsert the white Americanized masculinity. The story begins with the narrators description of the female character, Jeya:

Call it a black and white thing, though Jeya is not black. Not African black. Shes Ceylonese, born in Malaysia. Yet, her skin is blacker than the night. And she looks beautiful to me

The narrators conversation with Jeya whom he met on the first day of a 2 days writer's workshop is yoked by their common interest in the other with Jeya married to a white English man and the narrator with a colored Malay wife and prompted by two scantily dressed white female backpackers entering the restaurant. The two white women immediately become the focus of the narrators attention, interweaving his desire for them with his sexually-laden conversation with Jeya. The issue of race and sexual appetite is foregrounded only to function as a facade for the narrators male anxiety towards his own physical castration or to a certain extent his heterosexuality.

This is the result of him being asked by a female Chinese acquaintance: are you circumcised (ibid.)? His taciturnity in providing the answer to the question can be read as a sign of his refusal to admit his emasculation. The idea that the other a woman, colored, oriental who evokes this castration anxiety, extenuates his virility even further. Thus, the task of the subsequent narrative is to undermine and invalidate the others authority and existence allowing the expatriate narrator to in turn feel validated as a white American man.

This is achieved in two ways. First, the narrators strategy is to gradually eliminate Jeyas otherness. Jeya is made the narrators sexual object by the occasional punctuating of her exotic hence, castrated look throughout the narrative. In order to etiolate, Jeyas double otherness, i.e., both as a woman and a person of color, the narrator juxtaposes Jeyas appearance with that of a white girl he used to date back in college. Although, the woman was white, Jeya looks exactly like her. A twin sister in black skin.

Therefore, she becomes what Lacan suggests as the site of jouissance (Wright, 1992). This kind of twinning lets forth the idea that the narrator is not doubly castrated, since the castrating figure is now a white woman. Second, the narrators subsequent strategy having undermined and invalidated the others authority is to completely jettison the female characters including Jeya. At the end of the story, Jeya is no longer significant to the narrator and narrative: Jeya is saying something but I am no longer listening. The idea of women as invisible is nothing new especially in the theorization of the other which as Haste (1993) describes has to be cast as the antithesis of a masculine self. Jeyas position as the story concludes is antithetical to the expatriate narrator and her repudiation at the end of the story is compulsory and ideologically driven.

The motif of emasculated narrator is also prominent in on Fridays which narrates the journey taken by the protagonist in a taxi shared with three other passengers which according to the narrator is a metaphor for multiracial Malaysia where people from various races can live and work in close proximity and in relative harmony. The metaphor that panders to stereotype like a male Malay driver, a male Sikh as the passenger in the front, a bathetic Western gazer, a Malay damsel in distress with the mandatory white mans myopic exoticism that tantamount to eroticism and her antithesis a heavyset Indian woman, hardly constitute Malaysias multiracialism. What the taxi provides is a platform for staging the Western narrators sexual sojourn or even coitus prolongatus in which male orgasm is delayed (Rycroft, 1995).

The story is laden with male sexual imageries that belittle women and these are hard to ignore. But like any negative representation of a female character such as an exaggerated and highly stylized sexuality, the silver lining lies in the idea that that kind of representation ironically mirrors the male expatriate narrators sexual insecurity, struggling with his own sense of alienation and (sexual) urge: Oh why does not she just reach out and touch me and after struggling to close my umbrella (a phallic symbol), I finally shut the door reiterating what Lacan identifies as a signifier of phallocentricism (Wright, 1992). 
The taxi is gradually modulated into a place brimming with sexual imageries: a fan that makes a humming noise as it oscillates back and forth $[\ldots]$ the fog [...] [on] the front shield (which to the mind reminds us of a scene taken straight from a literally steamy sexual scene in a Hollywood soft-porn movie), inching closer and closer to the Malay woman, a dripping umbrella [... pressed against my left leg (an ubiquitous phallic symbol that keeps reappearing throughout this story) and I am practically sitting on top of her, twice the woman and I bump into each other and so on and so forth. At the end of the story, the Malay woman dominates my painting [...], a way of framing this Malay woman who could have been [his], confirming her status as ultimately the narrators white male voyeuristic object. This essentially mirrors the Western narrators fear of intimacy.

The othering of female characters in this collection of short stories is very prominent and ubiquitously represented by one single image in this case, a cockroach. The image of a cockroach appears in three stories: Symmetry, The station hotel and Sisters' room. In Symmetry, a little girls interest in a dead cockroach is a metaphor for the third person narrators own voyeuristic obsession with the female body. In the opinion, the narrator consciously aligns his gaze with that of the little girl therefore, concatenating the girls inspection of the body of the cockroach with her growing awareness of her own female body and sexuality. Primitive and dead, the cockroach evokes what Julia Kristeva calls abjection which in this case refers to Kristevas discussion of the human body in relation to her notion of the feminine body (Creed, 1997).

In the context of the story, the feminine body is therefore, seen as decayed and contaminated, hence having the effect of a pollutant. Conterminous with that what the narrator by extension the writer is saying is that the [dead] cockroach looks no different from the live cockroaches, highlighting the idea that a female body in effect is an abject essence. The idea that her brother poked her ribs points and laughs at her (ibid.) at the end of the story reinforces the notion that the female body is there to be penetrated and poked fun at.

The emasculation of the narrator is ironically mirrored in the representation of the feminine body as decayed and contaminated. This archaic representation continues in the station hotel and sisters room. The station hotel is a story about a rendezvous of secret lovers, Michele and Lee at the said hotel. Michele is married but living apart from her husband. Lee is married to a part-time Eurasian model wife, Yolanda and is having a marital problem. The choice of the place for their rendezvous is actually made by Michele as a personal joke as it is the place where she and her husband had stayed en route to their honeymoon destination in Hong Kong. It is during Michele and Lee's meeting at the hotel that both realize that they are no longer happy to be together. After a hostile day out and dinner, Michele is startled by what she thought was a cockroach and all at once she felt exhausted. This experience of seeing a cockroach can be read as symptomatic of her awareness of her polluted female body and self which Lee has realized before she does, consequently vetoed her suggestion of taking a bath together (ibid). Her response upon seeing the cockroach is indicative of the narrators vision of female sexuality as causing both mental and physical exhaustions that strained their relationship. Though, the narrator of this story detaches himself as the third person, his point of view is nonetheless gendered.

In Sisters' room, dramatic irony is created by Raymer through a naive and innocent little girl as an unreliable narrator. Sisters' room as the title suggests is about a little Malaysian Indian girls obsession with her sister's room without realizing that her sister, the sole breadwinner of the family, gets a special treatment from her almost destitute family so that she can entertain her male customers there.

The room for the little girl is a place where the family treasures are hidden. In the context of the story, the room can be read as a metaphor for hidden and forbidden female sexuality and the American writer explores this by equating it with a brothel-like space, signaling his view of female sexuality as something dirty and disgusting. The image of a cockroach that seeks refuge beneath the closed door of sisters room reinforces this very idea. Moreover, the little girls obsession with the sisters room evokes the image of female sexuality not only as corrupt and polluted but also predetermined and destined, making this a very dark story.

This sense of determinism is proven which upon the tragic death of her sister her father and an uncle-cum-pimp turn and look at me. They are looking real hard as if boring a hole through my head. This hardboiled narration when amalgamated with the girls plangent gullibility, lets forth vestiges of Raymer's own emasculation.

\section{THE OUTSIDER WITHIN AND ITS DISILLUSIONMENT}

Robert Raymer's narrators albeit tapping into the Malaysian consciousness and the thematic concerns of urban life and love (Merican et al., 2004) as well as creating literary representation of personal scripts (Raihanah) as seen in many new writings by Malaysians, present a distinct outsiders voice. The sense of detachment and impassivity with which the writer 
captures the stories of the different Malaysians, he encounters reiterates the authors own dilemma of being an outsider within.

There are certain characters who appear to embody the writer's voice. And it is through these characters that we the readers are given a glimpse into Raymer's subconscious positionality, the point of view that is coloured by his status as an expatriate. His written words, ironically, undermine his own claim of affinity and proximity with the Malaysians and Malaysia as one of the characters in Miss Valerie observes thats what the writers do; they kill with their words because they are cowards. Raymer's collection of short stories which began with the writer's acknowledgment of his hyphenated positionality as connected through marriage insider epitomizes the American writers disillusionment as the outsider within. Although, the stories contain universally transcendental message the eternal need for human contact hence, Lovers and Strangers Revisited, Raymer when he is successful is clever in depicting local landscapes and domestic mise-en-scenes via his variant narrative voices which in effect can sometimes carry an extra ironic freight; the volatility of narrators accounts of the events creates a sense of complicity in the reader. In neighbor for instance, the reader is consigned into an almost accidental role of an eavesdropper. In Sisters' room, the reader is put in a vacillating moral position, exacerbated by the storys dramatic irony, to become complicit in pedophilia and family tragedy.

Nonetheless, where Raymer is unsuccessful like in the station hotel and the stare, the descriptions of Malaysian landscapes seem abysmal and contrived: standing sentinel, a row of palm trees swayed gently in the breeze and Coaxed by a breeze, the leaves of the banana trees scraped against one another, respectively. To a great extent, these stories are American dreams gone away and local landscapes are used as a muse for an Americans vision of what Malaysian Dreams should look like.

For women readers likewise, this male vision would remind them of the first line by Du Maurier (1976), Rebecca last night, I dreamt. I went to Manderley again indicating a spiral journey downward.

As illustrated in this study, the narratological space constructed in this anthology is self-conscious, illusory and ironic. Instead of creating spatial proximity, the narratological space functions as a conduit for imposing the authors' masculine American gaze on the vision of what he thinks constitutes Malaysia or Malaysians, especially on the female characters.
In order to do that Raymer resorts to the construction of Malaysian women as the other that is his antithesis that would in the opinion, ironically, reveal his own sense of emasculation and disillusionment. This kind of representation of the local women can be a metaphor for the feminization of Malaysian dream itself allowing the connected through marriage insider writer to put himself on a pedestal while looking down at Malaysians and Malaysia.

\section{CONCLUSION}

It is within the American expatriates view and his mythos that the journey West symbolizes the promised frontier of hopes and dreams. Raymer's journey East, however is filled with nightmares and xenophobia thus, undermining the validity of his claim of a connectedthrough-marriage insider. Raymer aptly quoted Joseph Conrads Heart of Darkness in the books preface: we live as we dream alone, evoking his American individualism, existential bitterness, his romantic forlornness and disillusionment. We concur that that there is nothing new about this outsider representation as the originality of his work still harks back to the colonial/imperialist mindset as shown by his subconscious framing of his fiction with the quotation from the renowned colonialist adventurer, Conrad. Conversely, the perpetual trapping of the imperialist construct of the other in the anthology is alarming especially after nearly 60 years of Malaysian independence and after the world has undergone globalization.

The continued shackling of the other through a disguise of the insider ironically showcases the latters romantic forlornness, emasculation and disillusionment. The fact that Raymer is not a complete outsider but an insider/outsider situated in Malaysia exacerbates and complicates this misrepresentation even more. Perhaps, he would one day discover that what happens between lovers and strangers need not have to be bleak and gloomy all the time, i.e., if he cares to remember that the sun though sets in the West, rises from the East.

\section{REFERENCES}

Aziz, J., 2008. Incarcerated Male: The Crisis of Masculinity in Prison Narratives. In: Exploring Space: Trends in Literature, Linguistic and Translation, Manan, S. and L. Sinha (Eds.). Cambridge Scholars Publishing, London.

Creed, B., 1997. The Monstrous-Feminine: Film, Feminism and Psychoanalysis. Routledge, London.

Du Maurier, D., 1976. Rebecca. Pan Books, London. 
Haste, H., 1993. The Sexual Metaphor. Harvester Wheatsheaf, New York.

Lee, L.L., 1965. Walter van tilburg clarks ambiguous american dream. College English, 5: 382-387.

Merican, F., R.S. Hashim, G. Subramaniam and R.M. Mydin, 2004. Voices of Many Worlds: Malaysian Literature in English. Marshall Cavendish, Tarrytown, NY USA.

Naremore, J., 1998. More than Night: Film Noir in its Contexts. 1st Edn., University of California Press, Berkeley, pp: 342.
Raymer, R., 2005. Lovers and Strangers Revisited. Silverfishbooks, Kuala Lumpur.

Raymer, R., 2006. Lovers and Strangers Revisited. The New Straits Times, Malaysia.

Rycroft, C., 1995. A Critical Dictionary of Psychoanalysis. 2nd Edn., Puffin, London, pp: 256.

Wright, E.L., 1992. Feminism and Psychoanalysis: A Critical Dictionary. Wiley-Blackwell Publishers, Oxford, pp: 504. 